\title{
Spatial and seasonal distribution of the hermit crab Pagurus exilis (Benedict, 1892) (Decapoda: Paguridae) in the southwestern coast of Brazil
}

\author{
Distribución espacial y temporal del cangrejo ermitaño Pagurus exilis (Benedict, 1892)
}

(Decapoda: Paguridae) en la costa sudoccidental de Brasil

\author{
Andrea L. Meireles ${ }^{1 *}$, Mariana Terossi ${ }^{*}$, Renata Biagi ${ }^{1}$ and Fernando L. Mantelatto ${ }^{{ }^{*}}$ \\ ${ }^{1}$ Laboratory of Bioecology and Crustacean Systematic, Department of Biology, Faculty of Philosophy, Sciences and Letters of \\ Ribeirão Preto (FFCLRP), University of São Paulo (USP), Av. Bandeirantes 3900, CEP 14040-901, Ribeirão Preto, \\ São Paulo, Brazil; \\ *Program of Post Graduation on Comparative Biology - FFCLRP/USP. \\ flmantel@usp.br
}

\begin{abstract}
This study aimed to assess the spatial and seasonal distribution of the hermit crab Pagurus exilis in Caraguatatuba region, characterizing the abundance and distribution of individuals seasonally and bathymetrically. The relationship between groups of individuals and environmental factors (temperature, salinity, depth, amount of organic matter and texture of sediment) was checked. Sampling was carried out monthly from July 2001 to June 2003, at seven depths (5, 10, 15, 20, 25, 30 and $35 \mathrm{~m}$ ), with a shrimp fishery boat equipped with two double-rigged trawling nets. A total of 1960 specimens of $P$. exilis were collected, including 1369 (69.9\%) males, 304 (15.5\%) non-ovigerous females and 287 (14.6\%) ovigerous females. The individuals were distributed between 15 and $35 \mathrm{~m}$ and were absent at $5 \mathrm{~m}$. A large amount of individuals was collected (40.6\%) during winter and 57.8\% of ovigerous females were also captured in the same period. Pagurus exilis tended to occur in association with a group of factors composed by: higher depths (15 to $35 \mathrm{~m}$ ), higher salinity (34 to $37 \mathrm{psu}$ ), lower temperature (18 to $24^{\circ} \mathrm{C}$ ), and sediment of organic matter varying from 1 to $9 \%$.
\end{abstract}

Key words: Crustacea, Anomura, population, environmental factors, abundance
Resumen.- Este estudio tuvo por objetivo determinar la distribución espacial y temporal del cangrejo ermitaño Pagurus exilis en la región de Caraguatatuba, caracterizando la abundancia y distribución en función de la estación del año y profundidad. Se determinaron las relaciones entre los individuos y algunos factores abióticos (temperatura, salinidad, profundidad, concentración de materia orgánica y textura del sedimento). Las capturas fueron realizadas mensualmente, entre julio de 2001 y junio de 2003, en siete profundidades (5, 10, 15, 20, 25, 30 y $35 \mathrm{~m}$ ), utilizando dos redes de arrastres. Se obtuvo un total de 1960 individuos de $P$. exilis, incluyendo 1369 (69,9\%) machos, 304 (15,5\%) hembras no ovígeras y $287(14,6 \%)$ hembras ovígeras. Los animales estuvieron distribuidos entre 15 y $35 \mathrm{~m}$ de profundidad y ausentes en $5 \mathrm{~m}$. La mayor cantidad de individuos (40,6\%) fue obtenida durante el invierno y así como 57,8\% de las hembras ovígeras. La presencia de Pagurus exilis parece estar relacionada con la combinación de algunos factores abioticos tales como profundidad (15 y 35 $\mathrm{m})$, alta salinidad (34 a $37 \mathrm{psu})$, temperatura baja $\left(18\right.$ a $\left.24^{\circ} \mathrm{C}\right)$, y concentración de materia orgánica entre 1 y 9\%.

Palabras clave: Crustacea, Anomura, población, factores abióticos, abundancia

\section{Introduction}

The presence and the success of an organism or a group of organisms depend on a complex of factors. Each organism occupies one definitive space where the environmental and biotic conditions, are at least, the minimums necessary to propitiate its survival (Mantelatto et al. 1995, Pulliam 2000). It is of consensus among researchers that sea benthic species have their distribution and abundance limited by the temperature, salinity, depth, texture of the sediment, organic matter, beyond the intra and inter-specific relations, and these environmental factors can act in isolated or joint form.

According to Mantelatto et al. (1995), the spatial distribution of marine organisms becomes difficult to understand when the ocean and the complex 
relationship between abiotic factors are analyzed. Coastal zones are variable ecosystems, directly subject to continental, atmospheric and oceanic influences. Consequently, the instability of the coastal zone affects the benthic community, determining the patterns of distribution and density of the species (Santos \& PiresVanin 2004). For this reason, continuous and detailed studies of species with important role, such as decapod crustaceans, on dynamic of small areas such as bay and inlets may contribute to the understanding of distribution mechanism in marine complexes (Mantelatto 2000).

One of the variables that are considered of extreme importance in the distribution of species of marine benthic crustaceans is the sediment texture (Abele 1974); therefore, the grain composition can favor or limit the presence of many of these species (Pinheiro et al. 1996). According to Abele (1974), the decapods use the sediment first as shelter and as nutrition source, and the texture constitutes an essential element for the development of species with burrowing behavior (Mantelatto et al. 2004). Associated to the sediment, the percentage of the organic matter is considered of great importance in studies on the distribution of the marine organisms, mainly if it considers that the benthic animals feed on sediment (Pinheiro et al. 1996), or on organisms associated to it. According to Fransozo et al. (1998), the sediment texture and the amount of organic matter were the factors that most influenced the distribution and maintenance of anomurans' populations in Ubatuba Bay, northern coast of São Paulo State, because both factors are food resources valid for benthic organisms.

Anomuran decapods include a wide variety of forms, such as the attractive hermit crabs. Despite the world-wide interest in this group, distributional aspects of benthic communities have been studied less frequently, possibly because of the difficulties on sampling design on coastal zones, the heterogeneity and the intriguing aspects on relationship and dependence of gastropod shell for hermit survivorship, which complicates generalizations on distributional models ( $\mathrm{F}$. Mantelatto pers. com.).

Pagurus exilis (Benedict, 1892) is endemic to the southwestern Atlantic coast, and occurs in Brazil (Rio de Janeiro to Rio Grande do Sul), Uruguay and Mar del Plata (Argentina). Despite the considerable number of studies that reported the bio-geographic occurrences and systematic approaches of $P$. exilis (see Melo 1999 for review), the information on biology or ecology aspects is scanty. The detailed studies available deal with the post-embryonic development, shell occupation and the population biology (Scelzo \& Boschi 1969, Terossi et al. 2006, Mantelatto et al. in press, respectively).

Since very little information is available on distributional aspects of hermit crabs assessed by systematized study performed over a long period, we investigated the spatial and seasonal distribution of $P$. exilis in Caraguatatuba region, northern coast of São Paulo State, characterizing the abundance and distribution of individuals seasonally and bathymetrically. The relationship between groups of individuals (males, non-ovigerous females and ovigerous females) and environmental factors (temperature, salinity, depth, amount of organic matter and sediment texture) was checked to provide some baseline to help the previously existing gap on the knowledge of the determinants of the hermit crab distribution.

\section{Material and methods}

The collections were made monthly from July 2001 to June 2003, comprising seven depths (5, 10, 15, 20, 25, 30 and $35 \mathrm{~m}$ ) per month, with a shrimp fishery boat equipped with two double-rigged trawling nets in Caraguatatuba region $\left(23^{\circ} 36^{\prime} 08^{\prime \prime}\right.$ to $23^{\circ} 43^{\prime} 07^{\prime \prime} \mathrm{S}$ and $45^{\circ} 08^{\prime} 30^{\prime \prime}$ to $45^{\circ} 20^{\prime} 03^{\prime \prime} \mathrm{W}$ ), northern coast of São Paulo State, Brazil. After collection, the animals were frozen. In the laboratory, hermit crabs were counted and removed from shells, and the sex was checked (based on the gonopores position). The animals were preserved in 80\% ethyl alcohol and have been deposited in the Crustacean Collection of the Department of Biology, Faculty of Philosophy, Sciences and Letters of Ribeirão Preto, University of São Paulo (CCDB-FFCLRP-USP) under the numbers 1201 to 1204.

For seasonal analysis, the months were grouped: spring (September, October and November), summer (December, January and February), autumn (March, April and May) and winter (June, July and August).

Abiotic samples and protocols of analysis followed Mantelatto \& Fransozo (1999). An eco-bathymeter coupled with a GPS was used to record depth at sampling sites. In each depth, sediment and water samples were collected for analysis of the environmental factors. Bottom water was collected with 
a Nansen bottle to register temperature and salinity. Sediment was sampled with a van Veen grab. To separate the different grain sized fractions the humid procedure was used; the first stage constituted in separating the silt + clay fraction from the other fractions. Following, two samples of $100 \mathrm{~g}$ were separated from sediment, which were washed in a bolter with mesh of $0,063 \mathrm{~mm}$, allowing the passage of silt + clay. After that, the remaining particles were dried in an oven at $70^{\circ} \mathrm{C}$ for $24 \mathrm{~h}$ and submitted to the technique of the distinguishing sieved, by means of six bolters of different meshes (2 mm, $1 \mathrm{~mm}, 0.5 \mathrm{~mm}, 0.25 \mathrm{~mm}$, $0.125 \mathrm{~mm}$ and $0.063 \mathrm{~mm}$ ), used orderly decreasing. The six different resultant weights of the sieved were grouped in three categories: gravel, sand and mud. The amount of organic matter was obtained by means of the weight free from ashes, expressed in percentage.

Multiple regressions were used to check the existence of relation between the number of individuals and each environmental factor (depth, temperature, salinity, organic matter and sediment texture). The environmental parameters from depths and season and the occurrences of individuals among seasons were compared by ANOVA, and Tukey test were run for a posteriori comparisons $(P<0.05)$ (Zar 1996).

\section{Results}

\section{Environmental Factors}

The mean sampling period temperature was $21.9 \pm 2.32$ ${ }^{\circ} \mathrm{C}$, with the minimum value $\left(16.2^{\circ} \mathrm{C}\right)$ being registered in November-2001 and the maximum value $\left(28.2^{\circ} \mathrm{C}\right)$ in March-2003. There was a significant difference among the depths and the months along the sampling period, with temperature decreasing as the depth increased.

Salinity presented low variations between the sampled depths, but there were significant differences among the sampled months. The mean sampling period salinity was $35.3 \pm 1.26 \mathrm{psu}$, and the lowest value (30.0 psu) was registered in August-2002 and the highest value (37.0 psu) in several months (August, September and October-2001, and January, April, May and October-2002).

There was no significant difference in organic matter among the season, but there were variations among sampled depths. Percentage of organic matter increased with depth increasing, reaching the maximum value at $20 \mathrm{~m}$, and then there was a gradual decrease. The mean organic matter during the sampling period was $3.6 \pm$ 2.04\%; the minimum value $(1.1 \%)$ was registered in January-2003 and the maximum value (12.8\%) in August-2002.

There was no difference in sediment composition for the same depth during the season sampled. The gravel percentage increased according to the increase of depth. The mud percentage was relatively low at $5 \mathrm{~m}$, increased with the depth increasing, reached the maximum value at $15 \mathrm{~m}$, and then gradually decreased. The opposite was registered for the sand percentage; it was observed high percentage at $5 \mathrm{~m}$ and a decrease with increasing of the depth; reached the minimum value at $15 \mathrm{~m}$, and then gradually increased.

\section{Distribution of Pagurus exilis}

From a total of 1960 specimens collected, there were 1369 (69.9\%) males, 304 (15.5\%) non-ovigerous females and 287 (14.6\%) ovigerous females. The highest hermit crab occurrence (40.6\%) was observed during the winter in respect to the other seasons, when $57.8 \%$ of ovigerous females were also captured. There was a decrease in the number of captured individuals during spring $(P=0.004)$ (Fig. 1).

There was multiple regression significant between the abiotic factors and the number of the individuals (multiple $\mathrm{R}=0.343, P=0.005$ ), males (multiple $\mathrm{R}=$ $0.384, P=0.0005$ ) and non-ovigerous females (multiple $\mathrm{R}=0.364, P=0.002$ ). However there was not multiple regression significant between the abiotic factors and the ovigerous females (multiple $\mathrm{R}=0.258, P=0.127$ ).

The specimens occurred more frequently between 15 and $35 \mathrm{~m}$ of depth (Fig. 2), but the highest number of individuals was observed at $25 \mathrm{~m}$ (28.2\%). The individuals were absent at $5 \mathrm{~m}$, corroborated by regression detected between depth and the number of individuals $(P=0.042)$, number of males $(P=0.001)$ and number of non-ovigerous females $(P=0.034)$ (Table 1). Although no significant regression was detected between depth and the number of ovigerous females (Table 1), the highest abundance of these individuals (81\%) was observed in depths of 15, 20 and 25 m (Fig. 2). 

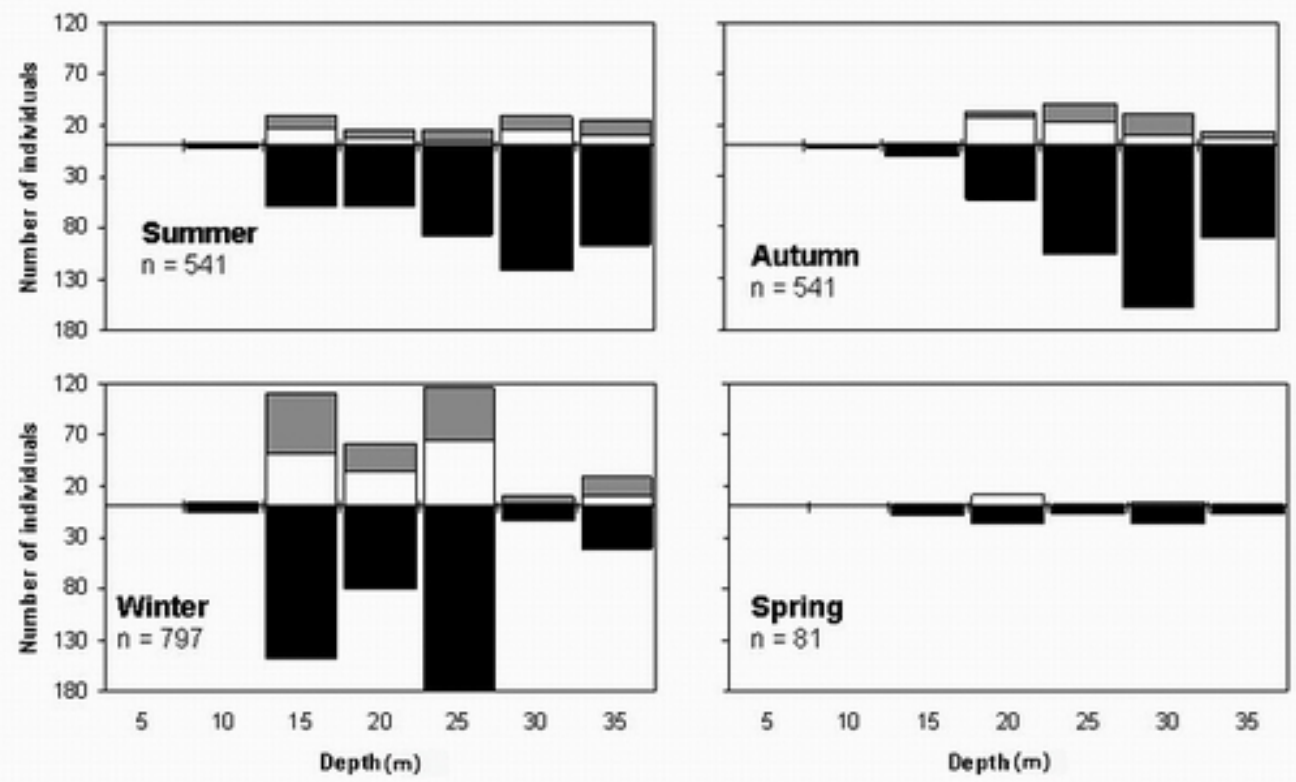

- Males ( $n=1369)$

$\square$ Non-ovgerous fem ales $(n=304)$

口Ovigerous fem ales $(n=287)$

\section{Figure 1}

Pagurus exilis. Number of individuals $(n=1960)$ collected in Caraguatatuba from July 2001 to June 2003 in each season and depth

Pagurus exilis. Número de individuos (n=1960) recolectados en Caraguatatuba desde julio 2001 hasta junio 2003 en cada estación y profundidad

Table 1

Pagurus exilis. $P$ values of the multiple regression between number of individuals collected and environmental factors. *Significant correlation $(P<0.05)$

Pagurus exilis. Valores $\boldsymbol{P}$ de la regresión múltiple entre el número de individuos recolectados y los factores ambientales *= correlación estadística significativa $(P<0.05)$

\begin{tabular}{llccc}
\hline Environmental factors & Males & Non-ovigerous females & Ovigerous females & Total \\
\hline Temperature & 0.220 & 0.438 & 0.647 & 0.050 \\
Salinity & $0.027^{*}$ & 0.406 & 0.072 & $0.284^{*}$ \\
Depth & $0.001^{*}$ & $0.034^{*}$ & 0.103 & $0.042^{*}$ \\
Organic matter & 0.907 & 0.888 & 0.796 & 0.003 \\
Sediment & & & & \\
Gravel & 0.052 & 0.192 & 0.516 & 0.874 \\
Sand & $0.049^{*}$ & 0.186 & 0.512 & 0.090 \\
Mud & $0.046^{*}$ & 0.167 & 0.491 & 0.086 \\
\hline
\end{tabular}



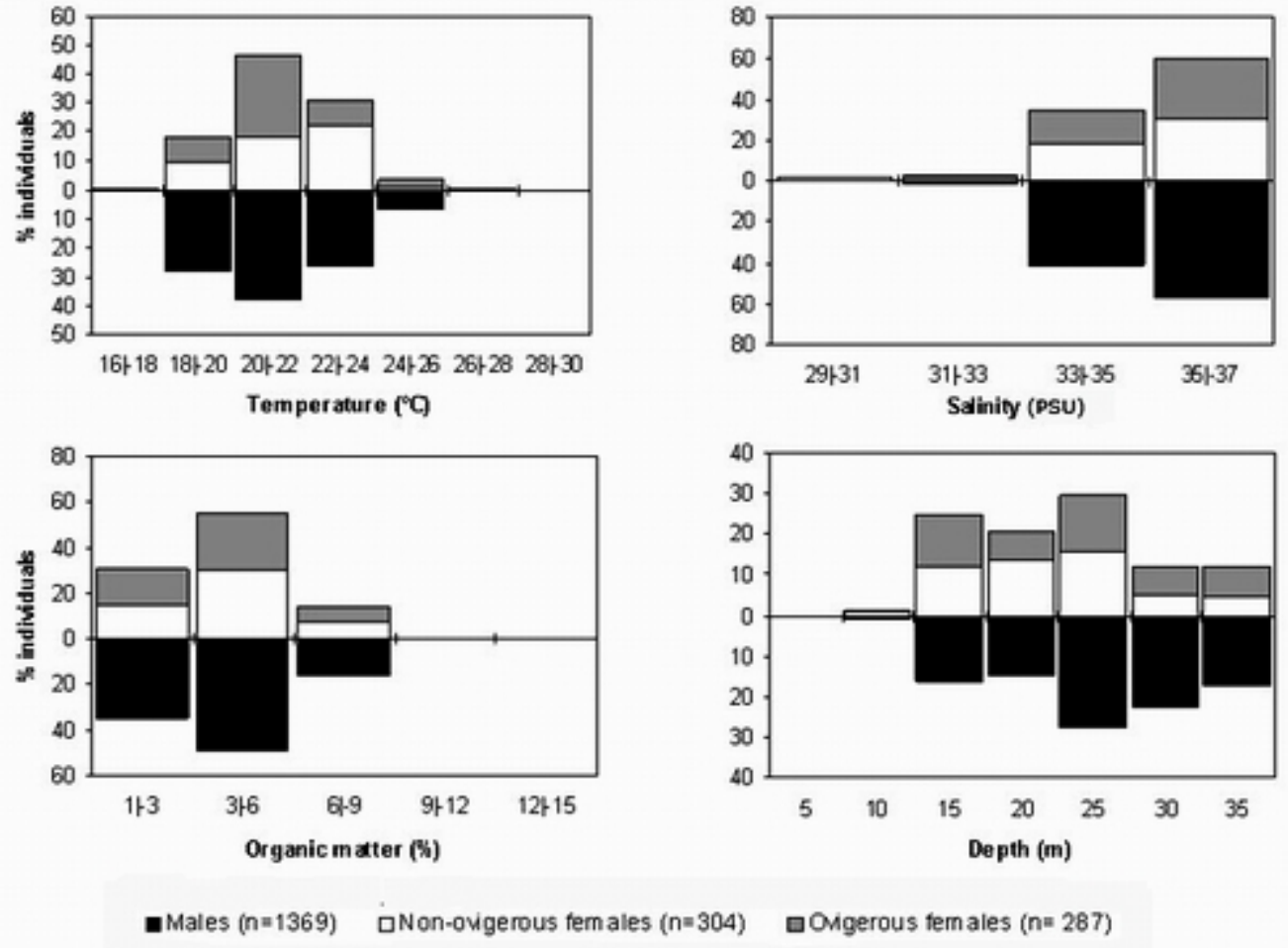

口OMgerous fernales ( $n=287$ )

Figure 2

Pagurus exilis. Relative percentage of individuals ( $n=1960)$ collected in Caraguatatuba from July 2001 to June 2003, in relation to abiotic factors

Pagurus exilis. Porcentaje relativo de individuos (n=1960) recolectados en Caraguatatuba desde julio 2001 hasta junio 2003 en relación a los factores abióticos

Significant regressions were detected between salinity and number of males $(P=0.027)$ and of all individuals collected $(P=0.284)$ (Table 1$)$, which corroborate the higher occurrence (97\%) of animals associated with high salinity (33 to 37 psu). Although no significant regression was detected between salinity and the number of ovigerous females (Table 1), there was absent of these individuals in the lowest salinity range (29 to 31 psu) (Fig. 2).

Significant regressions were not detected for temperature and organic matter $(P>0.05)$ (Table 1$)$. However there were larger individuals' frequencies in some environmental range. There was predominance of individuals (40\%) in class 3 of temperature (22 to $24^{\circ} \mathrm{C}$ ), absence of individuals in class 7 (28 to $\left.30^{\circ} \mathrm{C}\right)$, absence of ovigerous females in class $1\left(16\right.$ to $\left.18^{\circ} \mathrm{C}\right)$ and $6\left(26\right.$ to $28^{\circ} \mathrm{C}$ ) (Fig. 2). For organic matter the higher occurrence of individuals (99.8\%) was in class with smaller percentages (1 to 9\%) (Fig. 2).
Significant regression was detected between the occurrence of males and the percentage of mud ( $P=$ $0.046)$ and the percentage of sand $(P=0.049)$ (Table 1$)$.

\section{Discussion}

The abiotic characteristics obtained from Caraguatatuba region were similar to previous results for others bays in the northern coast region of São Paulo State (see Mantelatto \& Fransozo 1999 for review). This similarity between the areas occurs in function of similar geographic characteristics and because this region is affected by three water masses (Coastal Water, Tropical Water, and South Atlantic Central Water - SACW) with different distributional patterns in summer and winter (Castro Filho et al. 1987). The dynamics of these currents are responsible for seasonal alterations of temperature, salinity and nutrient concentrations (Costa et al. 2000). The temperature decrease observed in 
spring and summer was probably occasioned by the arrival of the SACW, a cold water mass, in the end of spring (Castro-Filho et al. 1987). Such condition resulted in the lowest value of temperature observed in November-2001. The arrival of the SACW in the region also promoted a relative salinity increase, which remained along this period, near $35 \mathrm{psu}$. The differences in the mean monthly salinity values can be resultant of some factors as water masses influence, tide action and rains that occur during the different months (Mantelatto et al. 2004). The values of salinity in the lowest depths probably were the smallest due the presence of freshwater in these places, coming from the rivers.

In general, the most important factors responsible for the spatial distribution of $P$. exilis in the Caraguatatuba region are depth, temperature and sediment characteristics, as it has been pointed out for other decapod crustaceans by many authors (Abele 1974, Pinheiro et al. 1996, Mantelatto et al. 1995, Fransozo et al. 1998, Mantelatto 2000). Particularly, the distribution by $P$. exilis is closely related with depths between 15 and $35 \mathrm{~m}$ and temperatures between 22 and $24^{\circ} \mathrm{C}$.

The major occurrence of ovigerous females was during the winter (July and August); although we observed a peak of these individuals in January-2002, that can be understood as an accidental occurrence. Other studies performed in the adjacent area showed that some infralittoral hermit crabs species also presented ovigerous females highest occurrence during winter, such as: Pagurus exilis (Hebling et al. 1994), Paguristes tortugae Schmitt, 1933 (Negreiros-Fransozo \& Fransozo 1992, Negreiros-Fransozo et al. 1992) and Loxopagurus loxochelis (Moreira 1901) (Martinelli et al. 2002). On the other hand, the reproductive period of other conspecific species occurred mainly during summer such as Calcinus tibicen (Herbst 1791) studied by Fransozo \& Mantelatto (1998) and Mantelatto \& Garcia (1999), Petrochirus diogenes (Linnaeus 1758) by Bertini \& Fransozo (2002), Paguristes erythrops Holthuis 1959 by Garcia \& Mantelatto (2001) and Pagurus criniticornis (Dana 1852) by Faria (2004).

The decrease in the $P$. exilis number of individuals during spring probably is associated with the South Atlantic Central Water arrival into the region, occasioning a temperature decrease and characterizing a decrease in the capture of hermit crabs, which might be in consequence of the individuals' migration to different deeper areas not sampled in the present study. This pattern of distribution was also reported to $L$. loxochelis in the region (Mantelatto et al. 2004).

During the spring and summer periods the ocean chlorophyll content (phytoplankton production) is higher, usually when the SACW intrudes into the region during upwelling events (Vega-Pérez 1993). The phytoplankton production leads to subsequent production of herbivorous zooplankton providing to the highest density of planktonic organisms in summer (Pires-Vanin \& Matsuura 1993). This variation coincides with the changes in frequencies of different group of individuals observed during the studied period suggesting that food availability for larvae and adults may be an important selective factor shaping the seasonal population pattern in $P$. exilis.

Pagurus exilis inhabits mainly subtropical waters of Argentina with low annual mean temperature (Scelzo \& Boschi 1973), which was corroborated by the higher occurrence of individuals under temperature smaller than $25^{\circ} \mathrm{C}$ in the studied area. These authors also studied the anomurans' geographic distribution in the Argentinean coast and registered the occurrence of $P$. exilis in temperatures between 8 and $25^{\circ} \mathrm{C}$. In the present study $P$. exilis was preferentially distributed in transects with mean temperatures from 18 to $24^{\circ} \mathrm{C}$, which may be considered low for the subtropical region studied. A conspecific hermit crab species, Dardanus insignis (Saussure 1858), also inhabits areas with low temperatures in Caraguatatuba region (Meireles pers. com.). The ovigerous females' low occurrence in depths with temperature lower than $20^{\circ} \mathrm{C}$ might be recurrent to this non propitious temperature to the reproduction or hatching embryos of $P$. exilis (Southward \& Southward 1977), also associated with planktonic production.

The captured individuals mainly inhabited areas with highest salinity values (34 to 37 psu). In Caraguatatuba, the conspecific hermit crab, $D$. insignis also inhabits areas with high salinity (Meireles pers. com.). Furthermore, $P$. exilis ovigerous females were not captured in depths with salinity values lower than 31 psu. Low salinity could affect negatively the embryos (Giménez \& Anger 2001), so females could migrate actively to areas with high salinity when they are ovigerous. Similar pattern of occurrence (low occurrence in low salinities) was reported to ovigerous females of Pagurus geminus McLaughlin 1976 in the Japanese coast (Imazu \& Asakura 1994). Nevertheless, others species may prefer lower salinity values, such as Isocheles sawayai Forest \& Saint Laurent 1967 that was 
registered in places with salinities of 33 psu. (NegreirosFransozo et al. 1997). Sometimes the distribution pattern shown by ovigerous females appears to support the hypothesis of allocation in function of reproduction condition, with the establishment of sites favorable to protection and egg incubation by ovigerous females and larval dispersion (Mantelatto 2000).

Mantelatto et al. (2004) reported the high occurrence of $L$. loxochelis associated with low temperatures and high salinities in Ubatuba Bay. This species is considered the most resembled to the $P$. exilis distribution pattern, although $L$. loxochelis occurred preferentially in lower depths (14 to $17 \mathrm{~m}$ ) than $P$. exilis. In Caraguatatuba, L. loxochelis presented the same pattern, but with highest occurrence at $20 \mathrm{~m}$ of depth (Peres 2005), probably avoiding competition.

The highest incidence of individuals was registered in the depths with the lowest mean percentages of organic matter (3 to 6\%). Nevertheless, others species prefer areas with highest (10 to 30\%) organic matter percentages (Bertini \& Fransozo 1999). According to these authors, organic matter can be accumulated on or deposited among sediment particles, constituting a food source for benthic organisms. Some species use the sediment like shelters, however, other species can obtain food in the substrate (Fransozo et al. 1998); these species are called deposit-feeders, like the studied hermit crab species.

Pagurus exilis presented higher occurrence in depths with heterogeneous fractions of sediments, mainly by sand and gravel. Nevertheless, others species inhabit preferentially areas constituted mainly by thin sediments (mud) like L. loxochelis (Mantelatto et al. 2004).

The relationship between $P$. exilis and the environmental factors evidenced that several environmental factors are acting together in the distribution pattern of this species. In this sense, we may conclude that: low temperature, high salinity, areas deeper than $15 \mathrm{~m}$ and heterogeneous substrates are the main features that influence the spatial and seasonal distribution of $P$. exilis in Caraguatatuba region, northern coast of São Paulo State, Brazil. Future biological studies (i.e. shell availability and selection, competition, predation and larval development) are needed to increase the knowledge about the factors that influence this species distribution and also to understand the dynamics of the whole hermit crab community nearby.

\section{Acknowledgements}

This research is part of a Bachelor thesis by MT and was supported by a Scientific Initiation Fellowship from FAPESP (Proc. 03/05408-6). ALM is grateful to FAPESP (Proc. 02/01646-7) for Ph.D. on-going fellowship; FLM and RB to CNPq for Post Doctoral (Proc. 150581/2003-3) and Research (Proc. 301261/040 ) on-going fellowships, respectively. Special thanks are due to Dr. Adilson Fransozo for support and facilities during sampling collections provided by FAPESP Biota Program (Proc. 98/07090-3), and to all NEBECC colleagues and to members of the Laboratory of Bioecology and Crustacean Systematic of FFCLRP/USP for their help during field and laboratory work, and two anonymous reviewers that provided helpful comments on earlier version of this manuscript. All experiments conducted in this study comply with current applicable state and federal laws.

\section{Literature cited}

Abele LG. 1974. Species diversity of decapod crustaceans in marine habitats. Ecology 55: 156-161.

Bertini G \& A Fransozo. 1999. Spatial and seasonal distribution of Petrochirus diogenes (Anomura, Diogenidae) in the Ubatuba Bay, São Paulo, Brazil. Iheringia Série Zoologia 86: 145-150.

Bertini G \& A Fransozo. 2002. Breeding season of the hermit crab Petrochirus diogenes (Anomura, Diogenidae) in the north coast of São Paulo state, Brazil. In: Escobar Briones E \& F Alvarez. pp. 145-150. Modern Approaches to the Study of Crustacea. Kluwer Academic/Plenum Publishers, New York.

Castro-Filho BM, LB Miranda \& SY Miyao. 1987. Condições hidromórficas na plataforma continental ao largo de Ubatuba: variações sazonais e em média. Boletim do Instituto Oceanográfico 35 (2): 135-151.

Costa RC, A Fransozo, FL Mantelatto \& RH Castro. 2000. Occurrence of shrimp species (Crustacea: Decapoda: Natantia: Penaeidea and Caridea) in Ubatuba Bay, Ubatuba, SP, Brazil. Proceedings of the Biological Society of Washington 113: 776-781.

Faria FCR. 2004. Biologia populacional e padrão de ocupação e seleção de conchas pelo ermitão Pagurus criniticornis (Crustacea, Anomura, Paguridae) da Ilha Anchieta, Ubatuba (SP). Master Dissertation. USP Ribeirão Preto (SP), 56 pp. 
Fransozo A \& FL Mantelatto. 1998. Population structure and reproductive period of the tropical hermit crab Calcinus tibicen (Decapoda: Diogenidae) in the region of Ubatuba, São Paulo, Brazil. Journal of Crustacean Biology 18 (4): 738-745.

Fransozo A, FL Mantelatto, G Bertini, LC FernandezGóes \& JM Martinelli. 1998. Distribution and assemblages of anomuran crustaceans in Ubatuba Bay, north coast of São Paulo state, Brazil. Acta Biologica Venezuelica 18 (4): 17-25.

Garcia RB \& FL Mantelatto. 2001. Population dynamics of the hermit crab Paguristes erythrops (Diogenidae) from Anchieta Island, southern Brazil. Journal of the Marine Biological Association of the United Kingdom 81: 955960.

Giménez L \& K Anger. 2001. Relationships among salinity, egg size, embryonic development, and larval biomass in the estuarine crab Chasmagnathus granulata Dana, 1851. Journal of Experimental Marine Biology and Ecology 260: 241-257.

Hebling NJ, FL Mantelatto, ML Negreiros-Fransozo \& A Fransozo. 1994. Levantamento e distribuição de braquiúros e anomuros (Crustacea, Decapoda) dos sedimentos sublitorais da região da Ilha Anchieta, Ubatuba (SP). Boletim do Instituto de Pesca 21: 1-9.

Imazu M \& A Asakura. 1994. Distribution, reproduction and shell utilization patterns in three species of intertidal hermit crabs on a rocky shore on the Pacific coast of Japan. Journal of Experimental Marine Biology and Ecology 184: 41-65.

Mantelatto, FL. 2000. Allocation of the portunid crab Callinectes ornatus (Decapoda: Brachyura) in Ubatuba Bay, northern coast of São Paulo State, Brazil. Crustacean Issues 12: 431-443.

Mantelatto, FL \& A Fransozo. 1999. Characterization of the physical and chemical parameters of Ubatuba Bay, northern coast of São Paulo State, Brazil. Revista Brasileira de Biologia 59: 23-31.

Mantelatto FL \& RB Garcia. 1999. Reproductive potential of the hermit crab Calcinus tibicen (Anomura) from Ubatuba, São Paulo, Brazil. Journal of Crustacean Biology 19 (2): 268-275.

Mantelatto FL, A Fransozo \& ML Negreiros-Fransozo. 1995. Distribuição do caranguejo Hepatus pudibundus (Herbst, 1785) (Crustacea, Decapoda, Brachyura) na Enseada da Fortaleza, Ubatuba (SP), Brasil. Boletim do Instituto Oceanográfico 43 (1): 51-61.
Mantelatto FL, JM Martinelli \& A Fransozo. 2004. Temporal-spatial distribution of the hermit crab Loxopagurus loxochelis (Decapoda, Anomura, Diogenidae) from Ubatuba Bay, São Paulo State, Brazil. Revista de Biologia Tropical 51 (4): 47-55.

Mantelatto FL, Espósito DLA , M Terossi, R Biagi \& AL Meireles. In press. Population features of the hermit crab Pagurus exilis (Anomura, Paguridae) in Caraguatatuba region, Brazil. Aquatic Ecology.

Martinelli JM, FL Mantelatto \& A Fransozo. 2002. Population structure and breeding season of the south Atlantic hermit crab, Loxopagurus loxochelis (Anomura, Diogenidae) from the Ubatuba region, Brazil. Crustaceana 75 (6): 791-802.

Melo GAS. 1999. Manual de Identificação dos Crustacea Decapoda do Litoral Brasileiro: Anomura, Thalassinidea, Palinuridea, Astacidea. Editora Plêiade, São Paulo, 551pp.

Negreiros-Fransozo ML \& A Fransozo. 1992. Estrutura populacional e relação com a concha em Paguristes tortugae Schmitt, 1933 (Decapoda, Diogenidae), no litoral norte do estado de São Paulo, Brasil. Naturalia 17: 31-42.

Negreiros-Fransozo ML, A Fransozo, FL Mantelatto, JM Nakagaki \& MCF Spilborghs. 1992. Fecundity of Paguristes tortugae Schmitt, 1933 (Crustacea, Decapoda, Anomura) in Ubatuba (SP) Brazil. Revista Brasileira de Biologia 52 (4): 547-553.

Negreiros-Fransozo ML, A Fransozo, FL Mantelatto, MAA Pinheiro \& S Santos. 1997. Anomuran species (Crustacea, Decapoda) and their ecological distribution at Fortaleza Bay sublittoral, Ubatuba, São Paulo, Brazil. Iheringia Série Zoologia 83: 187-194.

Peres LA. 2005. Aspectos bioecológicos do ermitão Loxopagurus loxochelis (Moreira, 1901) (Anomura, Diogenidae) em duas áreas do Litoral Norte de São Paulo, Brasil. Master Dissertation. USP - Ribeirão Preto (SP), $150 \mathrm{pp}$.

Pinheiro MAA, Fransozo A \& ML Negreiros-Fransozo. 1996. Distribution patterns of Arenaeus cribrarius (Lamarck, 1818) (Crustacea, Portunidae) in Fortaleza bay, Ubatuba (SP), Brazil. Revista Brasileira de Biologia 56 (4): 705-716.

Pires-Vanin MAS \& Y Matsuura. 1993. Estrutura e função do ecossistema de plataforma continental da região de Ubatuba, Estado de São Paulo: uma introdução. Publicação Especial do Instituto Oceanográfico 10: 1-8.

Pulliam HR. 2000. On the relationship between niche and distribution. Ecology Letters 3: 349-361. 
Santos MFL \& AMS Pires-Vanin. 2004. Structure and dynamics of the macrobenthic communities of Ubatuba Bay, Southeastern Brazilian coast. Brazilian Journal of Oceanography 52 (1): 59-73.

Scelzo MA \& EE Boschi. 1969. Desarrolo larval del cangrejo ermitaño Pagurus exilis (Benedict) en laboratorio. Physis 29 (78): 165-184.

Scelzo MA \& EE Boschi. 1973. Aportes al conocimiento de la distribución geográfica de los crustáceos decápodos anomura del Atlántico Sudoccidental, frente a las costas argentinas. Trabalhos do V Congresso Latinoamericano de Zoologia 1: 204-216.

Southward AJ \& EC Southward. 1977. Distribution and ecology of the hermit crab Clibanarius erythrops in the Western Channel. Journal of the Marine Biological Association of the United Kingdom 57: 441-452.
Terossi M, DLA Espósito, AL Meireles, R Biagi \& FL Mantelatto. 2006. Pattern of shell occupation by the hermit crab Pagurus exilis (Anomura, Paguridae) in southern Atlantic region. Journal of Natural History 40(12): $77-87$.

Vega-Pérez LA. 1993. Estudo do zooplâncton da região de Ubatuba, Estado de São Paulo. Publicação Especial do Instituto Oceanográfico 10: 65-84.

Zar JH. 1996. Biostatistical analysis. 907 pp. Prentice-Hall, New Jersey.

Recibido el 1 de marzo de 2006 y aceptado el 3 de mayo de 2006 